\title{
When Cives Europae became bargaining chips: free movement of persons in the Brexit negotiations
}

\author{
Adam Lazowski ${ }^{1}$
}

Published online: 4 June 2018

(C) The Author(s) 2018

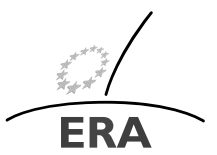

EUROPÄISCHE RECHTSAKADEMIE ACADEMY OF EUROPEAN LAW ACADEMIE DE DROIT EUROPEEN ACCADEMIA DI DIRITTO EUROPEO TRIER - TREVES - TREVIRI

\begin{abstract}
This article aims at taking stock of the Brexit developments thus far and provides the readers with an analysis of how, broadly understood, immigration has contributed to the results of the referendum and what role it plays in the negotiations between the EU and the UK.
\end{abstract}

Keywords Brexit · Immigration · Free movement · Withdrawal agreement

\section{Introduction}

Brexit negotiations, as anticipated, have proved to be a very complicated and multifaceted affair. ${ }^{1}$ One of the most controversial items on the agenda of the negotiating teams has been the rights of EU migrating citizens residing in the United Kingdom as well as UK nationals, who have been exercising their free movement rights in one of the Member States of the European Union. This dossier was bound to stir controversies from the start. ${ }^{2}$ Alas, the pre-referendum debate, as well as events that unfolded in its aftermath, have turned Cives Europae into bargaining chips. Whatever the outcome of these negotiations, or-in more general terms-Brexit itself, it is likely to leave a bitter aftertaste. This article aims at taking stock of the developments thus far

\footnotetext{
${ }^{1}$ See, exempli gratia, Fabrini [12]; Hillman/Horlick [18]; Dougan [8]; Emerson [10]; Peers/Harvey [35], p. 815. On EU withdrawal but in more general terms see, inter alia, Tatham [40], p. 128; Hillion [17], p. 142.

${ }^{2}$ See further Hughes [20], p. 94; Rieder [37], p. 147; Ederveen [9]; Lazowski [26], p. 523.
}

A. Łazowski

A.Lazowski@westminster.ac.uk

1 Professor of European Union Law, Westminster Law School, University of Westminster, London, UK 
and provides the readers with an analysis of how, broadly understood, immigration has contributed to the results of referendum (Sect. 2) and what role it plays in the negotiations between the EU and the UK (Sect. 3). ${ }^{3}$ In the latter part, the analysis will cover the tentative agreement on the status of EU/UK citizens post-Brexit. While the deal was reached in December 2017 and a draft Withdrawal Agreement was presented in February 2018, there were still leftovers to be dealt with in the course of 2018. Furthermore, the entry into force of the Withdrawal Agreement should not be treated as a fait accompli. Bearing this in mind, the readers are also offered an analysis of a hypothetical - for the time being - scenario of an unregulated withdrawal. Furthermore, a transitional period, which was being contemplated when this article was finalised, is also taken on board.

\section{Free movement of persons before and after the Brexit referendum}

\subsection{Build-up to the referendum}

As far as we can trace back the history of humankind, people have been migrating. ${ }^{4}$ Thus, this phenomenon is not, by any stretch of the imagination, an idiosyncrasy of the 20th and 21st century, but rather a process that goes back much longer. While the political, economic and technological environments have changed, the main reasons behind the migratory movements have-in general terms - stayed the same. People have moved around to conquer others' territories, in search of food, commodities, commerce or, to put it simply, in search of a better life. New modes of transport and technical innovations, which were developed in the 20th century, have also fed tourism, which over the past decades has become a commodity of its own. To put it differently, humans have become infected with a highly contagious disease frequently referred to as travelitis furiosus, which can be loosely translated as a difficult to sustain urge to travel. ${ }^{5}$ Within the European Union, the movement of persons across the borders has been considerably liberalised qua freedoms of the internal market as well as by the lifting of border controls as per the Schengen acquis. ${ }^{6}$ When it comes to the first, the key roles are played by free movement of workers, the right of establishment and the free movement of services. These three fundamental freedoms complement one another and have gone through a considerable evolution since the early days of the European Communities. The Treaty of Maastricht added a cherry to that cake: the concept of EU citizenship. While many political circles have treated it as mere shop window dressing, for the Court of Justice it has been a great opportunity to proceed with a pro-integration jurisprudence, putting the flesh on the bones of a skeleton

\footnotetext{
${ }^{3}$ The cut-off date for the present analysis is 26 February 2018.

${ }^{4}$ On history of migrations see, inter alia, Manning [30].

${ }^{5}$ As noted by G. Mikes, "Travel" is the name of a modern disease which became rampant in the midfifties and is still spreading. The disease-its scientific name is travelitis furious-is carried by a germ called prosperity.' See further Mikes [32], p. 105.

${ }^{6}$ See further on the evolution of Schengen acquis and its incorporation into the EU legal order Peers [34].
} 
concept. ${ }^{7}$ One should also remember that the Treaty of Maastricht has facilitated development of EU secondary legislation dealing with the rights of third country nationals. ${ }^{8}$ As expected, however, the free movement rights raise, in equal measure, excitement and anxiety. Arguably, the results of the Brexit referendum demonstrate the preponderance of the latter over the former. To put it differently, immigration has proven to be one of the leitmotifs of the referendum campaign and, consequentially, one of the reasons why the majority of voters, however slim, has opted for leaving the European Union. ${ }^{9}$ In order to appreciate that phenomenon, it is worth taking a closer look at the big picture, as it will provide a systemic background to the analysis that follows.

Since its creation in the 1950s, the European Communities (now the European Union) have progressed towards creation of the common market, later rebranded the internal market. Part and parcel of it, as noted above, are the free movement rights. The early secondary legislation shows that uncontrolled migration between the original six Member States was definitely feared. This was reflected in, exempli gratia, narrowing down of the freedom of movement to those economically active; and furthermore, by limiting its scope to those who benefited from job offers made before embarking on a journey to another Member State. ${ }^{10}$ While the latter condition was quickly dropped, other types of migratory movements remained governed by Member State national laws. It was only in the late 1980s that things started to change. Firstly, the Council adopted a package of three directives on non-economic residence rights. ${ }^{11}$ Secondly, as mentioned above, the Member States laid down the foundations for EU citizenship, with its flagship right to move and reside freely across the Member States. ${ }^{12}$ Changes in EU law have been accompanied by dramatic expansion of EU membership, which considerably increased the number of people entitled to the rights in question. As well-known, the European Communities (the Union) have expanded since the early days of an exclusive club of six to a total of 28 Member States, with the population exceeding 500 million people. ${ }^{13}$ Seven enlargement rounds covered not only rich countries but also the ones, which at the time of accession-and for years thereafter-had much lower GDP. This, for reasons which need no explanation, became one of the major factors dominating their rapprochement to the European Communities (Union). On the one hand, it was an ultimate incentive to persuade their populations of the benefits of European integration. On the other hand, it

\footnotetext{
${ }^{7}$ See, exempli gratia, Case C-85/96 María Martínez Sala v Freistaat Bayern, EU:C:1998:217; Case C413/99 Baumbast and $R v$ Secretary of State for the Home Department, EU:C:2002:493; Case C-34/09 Gerardo Ruiz Zambrano v Office national de l'emploi (ONEm), EU:C:2011:124; Case C-192/05 K. TasHagen and R. A. Tas v Raadskamer WUBO van de Pensioen- en Uitkeringsraad, EU:C:2006:676.

${ }^{8}$ This comprises, exempli gratia, EU legislation on visas, asylum and immigration. See further Peers [34].

${ }^{9}$ For an academic appraisal see, inter alia, Clarke/Goodwin/Whiteley [4].

${ }^{10}$ Règlement $\mathrm{n}^{\circ} 15$ relatif aux premières mesures pour la réalisation de la libre circulation des travailleurs à l'intérieur de la Communauté [1961] OJ 57/1073.

${ }^{11}$ Council Directive 90/364/EEC of 28 June 1990 on the right of residence [1990] OJ L 180/26; Council Directive 90/365/EEC of 28 June 1990 on the right of residence for employees and self-employed persons who have ceased their occupational activity [1990] OJ L 180/28; Council Directive 93/96/EEC of 29 October 1993 on the right of residence for students [1993] OJ L 31759.

${ }^{12}$ See van der Harst/Hoogers/Voerman [41].

${ }^{13}$ For a comprehensive analysis of EU enlargements see, inter alia, Tatham [39].
} 
was a source of major concern among the existing and considerably better-off Member States. Hence, in order to square the circle, the European Communities (Union) decided to add to the enlargement toolkit a set of multi-annual transitional periods permitting the Member States, both old and new, to provide for interim arrangements facilitating gradual phasing-in of free movement rights after accession. However, the said transitional periods were limited in time, with no permanent opt-outs from the free movement of workers available on the menu. ${ }^{14}$ With the big-bang enlargement of $2004,{ }^{15}$ the transitional regime in question has become a standard feature of the Accession Treaties, repeated in the cases of Bulgaria and Romania (2007) ${ }^{16}$ and Croatia (2013). ${ }^{17}$ This trend is likely to continue if/when the next rounds of enlargement take place. $^{18}$

While the idiosyncrasies of the enlargement policy deserve no further exploration in this article, it merits attention that the opening of the United Kingdom's labour market as of 1 May 2004 contributed considerably to the pre-referendum debate and

${ }^{14}$ Furthermore, the transitional regimes were limited to free movement of workers. Au contraire, neither of the recent Accession Treaties provided for general restrictions to the right of establishment. See Goldner Lang [14].

${ }^{15}$ Treaty between the Kingdom of Belgium, the Kingdom of Denmark, the Federal Republic of Germany, the Hellenic Republic, the Kingdom of Spain, the French Republic, Ireland, the Italian Republic, the Grand Duchy of Luxembourg, the Kingdom of the Netherlands, the Republic of Austria, the Portuguese Republic, the Republic of Finland, the Kingdom of Sweden, the United Kingdom of Great Britain and Northern Ireland (Member States of the European Union) and the Czech Republic, the Republic of Estonia, the Republic of Cyprus, the Republic of Latvia, the Republic of Lithuania, the Republic of Hungary, the Republic of Malta, the Republic of Poland, the Republic of Slovenia, the Slovak Republic, concerning the accession of the Czech Republic, the Republic of Estonia, the Republic of Cyprus, the Republic of Latvia, the Republic of Lithuania, the Republic of Hungary, the Republic of Malta, the Republic of Poland, the Republic of Slovenia and the Slovak Republic to the European Union [2003] OJ L 236/17. See, inter alia, Inglis [21], p. 937; Hillion [16], p. 583.

${ }^{16}$ Treaty between the Kingdom of Belgium, the Czech Republic, the Kingdom of Denmark, the Federal Republic of Germany, the Republic of Estonia, the Hellenic Republic, the Kingdom of Spain, the French Republic, Ireland, the Italian Republic, the Republic of Cyprus, the Republic of Latvia, the Republic of Lithuania, the Grand Duchy of Luxembourg, the Republic of Hungary, the Republic of Malta, the Kingdom of the Netherlands, the Republic of Austria, the Republic of Poland, the Portuguese Republic, the Republic of Slovenia, the Slovak Republic, the Republic of Finland, the Kingdom of Sweden, the United Kingdom of Great Britain and Northern Ireland (Member States of the European Union) and the Republic of Bulgaria and Romania, concerning the accession of the Republic of Bulgaria and Romania to the European Union [2005] OJ L157/11. See, inter alia, Lazowski [23], p. 401.

${ }^{17}$ Treaty between the Kingdom of Belgium, the Republic of Bulgaria, the Czech Republic, the Kingdom of Denmark, the Federal Republic of Germany, the Republic of Estonia, Ireland, the Hellenic Republic, the Kingdom of Spain, the French Republic, the Italian Republic, the Republic of Cyprus, the Republic of Latvia, the Republic of Lithuania, the Grand Duchy of Luxembourg, the Republic of Hungary, the Republic of Malta, the Kingdom of the Netherlands, the Republic of Austria, the Republic of Poland, the Portuguese Republic, Romania, the Republic of Slovenia, the Slovak Republic, the Republic of Finland, the Kingdom of Sweden, the United Kingdom of Great Britain and Northern Ireland (Member States of the European Union) and the Republic of Croatia concerning the accession of the Republic of Croatia to the European Union [2012] OJ L112/10. For an academic appraisal, see Lazowski [25], p. 1.

${ }^{18}$ According to the European Commission, the next enlargement may take place around 2025. This, however, is subject to a successful completion of the accession negotiations and ratification of accession treaty(ties). It should be emphasised that neither of the two should be taken for granted. See further Communication from the Commission to the European Parliament, the Council, the European and Social Committee and the Committee of the Regions: A credible enlargement perspective for and enhanced EU engagement with the Western Balkans, COM (2018) 65 final. 
cast a shadow on its results. While the campaign painfully lacked attention to detail and facts, it is unquestionable that in the past 10 years many Central and Eastern European citizens have put down roots in the United Kingdom. ${ }^{19}$ Not for the first and not for the last time migratory movements have altered the social fabric of the British Isles. Furthermore, one should not forget the immigration from third countries, including the United Kingdom's former colonies. ${ }^{20}$ Alas, immigration has become a toxic topic in public discourse and, to make things worse, a subject of unrealistic pledges made by the political elites. Instead of having a merit-based discussion about the benefits and the disadvantages of immigration, the voters were exposed to various versions of simplified and non-data based truths and assumptions that foreigners contribute little to the UK budget but, instead, milk the allegedly generous social system. The media coverage was frequently twisted, largely negative and consequentially contributed to this state of affairs. In such a political climate, the then Prime Minister David Cameron engaged in renegotiation of the UK's membership in the European Union. ${ }^{21}$ At the same time, a pledge to hold a referendum on the future of UK membership of the EU was made. ${ }^{22}$ For many this was yet another case of UK's exceptionalism and one more attempt at securing additional opt-outs from the mainstream integration endeavour. ${ }^{23}$ Driven by an unrealistic pledge to cap immigration numbers and without a clear agenda for renegotiation, the Prime Minister failed to secure major concessions from his European partners, yet managed to negotiate a few idiosyncratic rules, which he subsequently failed to sell persuasively to members of the public. ${ }^{24}$ The rest is history. ${ }^{25}$ On 23 June 2016 , by a slim majority, voters expressed a desire to leave the European Union, and, by the same token, to give up their EU citizenship. ${ }^{26}$ As noted above, immigration was one of the dominating themes during the pre-referendum campaign. ${ }^{27}$ To use the words of $\mathrm{H}$. Brady, the debate 'has generated more heat than light'. ${ }^{28}$ As noted by the present author in one of the earlier publications, the referendum itself raises doubts as to its democratic credentials, and, not surprisingly, this is inextricably linked to the substance of this article. ${ }^{29}$ A source of concern was the franchise, which excluded many beneficiaries of the EU free movement rights. To begin with, UK nationals, who have resided for over 15

\footnotetext{
${ }^{19}$ See House of Lords, Brexit: UK and EU movement of people, HL Paper 121, 2017, available at: https:// publications.parliament.uk/pa/ld201617/ldselect/ldeucom/121/121.pdf.

${ }^{20}$ See House of Lords: Brexit and the Labour Market, HL Paper 11, available at: available at: https:// publications.parliament.uk/pa/ld201719/ldselect/ldeconaf/11/11.pdf, at p. 21.

${ }^{21}$ As argued by some authors, the free movement of persons could have been limited without such complex negotiations. See Davies [7], p. 925.

${ }^{22}$ See further, inter alia, Copsey/Haughton [5].

${ }^{23}$ See further, inter alia, Lazowski [29].

${ }^{24}$ See further, inter alia, Weiss/Blockmans [44], pp. 8-11.

${ }^{25}$ On the political position of the UK in the EU around the time of negotiations see, inter alia, Kluger Rasmussen [22].

${ }^{26}$ For an appraisal of the referendum see, inter alia, Clarke/Goodwin/Whiteley [4].

${ }^{27}$ For a detailed account see, inter alia, Armstrong [1], pp. 73-85.

${ }^{28}$ Brady [3], p. 28.

${ }^{29}$ Eazowski [27].
} 
years outside the United Kingdom, had no right to vote. Furthermore, the EU citizens who exercised their fundamental right to move and have settled in the United Kingdom have been also deprived of voting rights. To make matters worse, the United Kingdom quietly tightened domestic rules on naturalisation. ${ }^{30}$ The timing and mechanics of the latter move left little doubt that the raison d'être behind the change was to stop EU citizens from acquiring UK citizenship and thus the right to vote in the forthcoming referendum. All in all, over 4 million people, whose residence rights have been put into question by the referendum results, had no say in what was meant to be an ultimate exercise in direct democracy. And, with the Brexit process unravelling, they have become bargaining chips as a consequence of being Cives Europae, who had exercised the rights stemming from their fundamental status.

\subsection{The morning, the week, the month, the year after...}

Not surprisingly, the referendum was followed by political turmoil. In the midst of unprecedented political crisis, calls were made to guarantee the acquired rights of EU/UK citizens. Alas, they fell on the deaf ears of the newly appointed government of Theresa May, whose anti-immigration prejudice was well-known from her previous job as Home Office Secretary. ${ }^{31}$ On the one hand, the government at regular intervals repeated statements emphasising appreciation for migrant workers supporting the British economy. ${ }^{32}$ On the other hand, no clear confirmation of guaranteed rights followed. Not surprisingly, EU citizens rushed to obtain permanent residence cards, which - as per Directive 2004/38/EC - have merely a declaratory character. ${ }^{33}$ Yet, under the circumstances, many applicants believed that the cards in question guaranteed an additional safety net at very uncertain times. It is notable that issuing of permanent residence cards is left in the hands of the Member States, while Directive 2004/38/EC provides only a very general framework. ${ }^{34}$ It quickly turned out that the modus operandi envisaged by the UK legislation was tedious and timeconsuming as if it were made to dissuade any potential applicants. To make things worse, it also proved to be far too demanding for the UK immigration authorities. ${ }^{35}$

\footnotetext{
${ }^{30}$ As of the autumn of 2015, EU citizens who wish to become naturalised need to obtain, as the first step, a permanent residence card, which—in accordance with Directive 2004/38/EC is not compulsory.

${ }^{31}$ See Wintour [46].

${ }^{32}$ Foreign \& Commonwealth Office, Prime Minister's Office, 10 Downing Street, Department for Exiting the European Union, The Rt Hon Theresa May MP, PM's Florence speech: a new era of cooperation and partnership between the UK and the EU, 22 September 2017, https://www.gov.uk/government/ speeches/pms-florence-speech-a-new-era-of-cooperation-and-partnership-between-the-uk-and-the-eu. For a commentary see, inter alia, Emerson [11].

${ }^{33}$ See Art. 25 of Directive 2004/38/EC (Directive 2004/38/EC of the European Parliament and of the Council of 29 April 2004 on the right of citizens of the Union and their family members to move and reside freely within the territory of the Member States amending Regulation (EEC) No 1612/68 and repealing Directives 64/221/EEC, 68/360/EEC, 72/194/EEC, 73/148/EEC, 75/34/EEC, 75/35/EEC, 90/364/EEC, 90/365/EEC and 93/96/EEC [2004] OJ L 158/77). For an academic appraisal see, inter alia, Guild/Peers/Tomkin [15], pp. 241-242.

${ }^{34}$ It should be noted that Directive 2004/38/EC provides only for a minimum standard and, as per Article 37, the Member States may provide for a more generous regime in their national laws. See further, Guild/Peers/Tomkin [15], pp. 241-242.
}

${ }^{35}$ See Warrel [42]. 
Some EU citizens opted for naturalisation in order to make sure that their rights are protected. This, however, means that they de-activated their EU free movement rights, even though their spouses may still, qua creative jurisprudence of the Court of Justice, benefit from rights derived as per Article 21 TFEU. ${ }^{36}$ In more general terms, the Brexit vote exacerbated anti-immigration sentiments with a considerable spike of hate crime. Furthermore, many media outlets, in particular the tabloid newspapers, followed suit and continued to picture immigrants as benefit dodgers, milking the UK social protection system. All of this took place against the solid evidence proving a plausible contribution of EU migrating workers and self-employed to the British economy. ${ }^{37}$ Furthermore, many a time the free movement of persons was presented in a one-sided fashion, as if the same rules did not apply to UK citizens migrating to other EU Member States. Arguably, an interesting semantic phenomenon emerged in the public discourse. While the EU citizens residing in the United Kingdom were labelled as 'immigrants', the UK citizens enjoying their fundamental EU right in one of the other Member States were referred to as 'expats'. It is against this general background that the negotiations of withdrawal negotiations commenced. Not surprisingly, the question of acquired rights of EU citizens in the UK, and the UK citizens in the EU, has been placed at the top of the agenda. At the same time, the rights of EEA-EFTA countries citizens residing in the UK (and UK citizens residing in the EEA-EFTA countries) as well as the status of the Swiss nationals residing in the UK (and UK citizens in Switzerland) were left untouched in a fairly nonchalant fashion. ${ }^{38}$

\section{Free movement of persons in Brexit negotiations}

\subsection{Brexit negotiations: the basics}

Even though the withdrawal procedure has a legal basis in EU Treaties, Article 50 TEU fails to address all pertinent issues, leaving much room for manoeuvre to the European Union. ${ }^{39}$ This extends, exampli gratia, to the choice of dossiers covered by the negotiations and the sequencing of withdrawal talks. The European Union has been granted additional flexibility by the UK government, which has proven to be patently unprepared for what has unraveled after the referendum. The sequencing has been of high importance, particularly because the European Union has insisted on a phased-in approach. To put it differently, the negotiations have been divided into two phases: the first devoted to terms of withdrawal and the second dedicated

\footnotetext{
${ }^{36}$ See Case C-165/16 Toufik Lounes v Secretary of State for the Home Department, EU:C:2017:862.

${ }^{37}$ See House of Lords: Brexit and the Labour Market, HL Paper 11, 2017, available at: https://publications. parliament.uk/pa/ld201719/ldselect/ldeconaf/11/11.pdf.

${ }^{38}$ See very vocal criticism of this state of affairs: House of Commons, Home Affairs Committee, Home Office Delivery of Brexit: Immigration, HC 421, available at: https://publications.parliament.uk/ $\mathrm{pa} / \mathrm{cm} 201719 / \mathrm{cmselect} / \mathrm{cmhaff} / 421 / 421$.pdf.

${ }^{39}$ As painfully proven during the negotiations with the United Kingdom, a departing country is by default in a much weaker position without a real impact on key procedural and substantive decisions regarding the exit negotiations.
} 
to nitty-gritty details and a framework for future relations. ${ }^{40}$ It should be noted that the opening of the second phase was made conditional on 'sufficient progress' in the early talks. Not surprisingly, the free movement of persons has been addressed in the opening phase, alongside the UK contributions to the EU budget and the border between the UK and Ireland. As argued by P. Craig, 'the position of EU citizens living in the UK, and UK citizens living in the EU, is regarded as central to the withdrawal agreement by both sides'. ${ }^{41}$ When this article went to print, the basic elements of the deal have been agreed to. A breakthrough came just ahead of the European Council meeting in December 2017, while the first draft of the Withdrawal Agreement was published by the European Commission on 28 February $2018 .^{42}$

In order to fully appreciate the idiosyncrasies of the agreed solutions it is necessary, as the first step, to take a closer look at the negotiating positions of both sides. Bearing in mind the post-referendum political shenanigans in the United Kingdom, it is hardly surprising that the European Union commenced the negotiations with a clear vision of what it wished to achieve, while Whitehall drowned in internal political negotiations within the ruling Conservative Party. A cacophony of ideas has quickly become spécialité de la maison of the UK Government, with floods of incoherent statements emerging from various members of the cabinet, including the Prime Minister herself. ${ }^{43}$ While the negotiating position of the EU in the area of free movement of persons proved to be strong and stable, the opening stance of the United Kingdom was weak and wobbly. Perhaps the most striking example was the state of the art in February 2018, when the European Union was ready to commence the second phase of withdrawal negotiations and preparation of negotiation positions was in full swing, while the UK government had no firm idea of plans ahead and the members of the government were busy delivering Brexit speeches, instead of getting on with the negotiations and other Brexit related challenges. ${ }^{44}$ Irrespective of that, one thing was clear for both sides: one of the most essential issues to be tackled in the Brexit

\footnotetext{
${ }^{40}$ See paras. $4-7$ of Guidelines of the European Council.

${ }^{41}$ Craig [6], p. 1.

${ }^{42}$ European Commission Draft Withdrawal Agreement on the withdrawal of the United Kingdom of Great Britain and Northern Ireland from the European Union and the European Atomic Energy Community, available at: https://ec.europa.eu/commission/publications/draft-withdrawal-agreement-withdrawalunited-kingdom-great-britain-and-northern-ireland-european-union-and-european-atomic-energycommunity_en.

${ }^{43}$ For instance during weekly questions to the Prime Minister at the House of Commons on 11 October 2017, the Prime Minister T. May said: 'On the second point, I made very clear-perhaps I need just to explain it again to members of the Opposition-that when we leave the European Union in March 2019, we will cease to be full members of the single market and the customs union. That will happen because you cannot be full members of the single market and the customs union without accepting all four pillars-free movement; continued, in perpetuity, European Court of Justice jurisdiction. During the implementation period, we will be looking to get an agreement that we can operate on much the same basis as we operate at the moment- under the same rules and regulations—-but that will not be the same as full membership of the customs union and the single market'. See https://hansard.parliament.uk/ commons/2017-10-11/debates/853E0598-0872-46DA-8734-360429BA8232/Engagements.
}

${ }^{44}$ See Barber [2]. 
negotiations had to be the rights of EU/UK citizens. ${ }^{45}$ This, however, as acutely put by J. Shaw, amounted to 'navigating an archipelago of contradictions'. ${ }^{46}$ As the negotiations commenced it became abundantly clear that 'it is [...] often easier to agree on general propositions than their detailed meaning'. 47

\subsection{Negotiating positions}

When it comes to the European Union, the most crucial decisions related to Brexit are taken by the European Council. This is not only dictated by its composition and formal role in the institutional line-up but, first and foremost, by its mandate, explicitly included in Article 50 TEU. ${ }^{48}$ A key role is also envisaged for the European Commission, which conducts the withdrawal negotiations. ${ }^{49}$ As per Article 50 TEU, for a withdrawal agreement to enter into force there is need not only for a decision of the Council but also consent by the European Parliament. Although the latter plays no formal role in the exit negotiations, it has proved to be a very active and vocal player ever since the United Kingdom held the referendum. As noted by K.A. Armstrong, 'the EP's role is an oversight and scrutiny role rather than a "negotiating" role'. 50 Still, however, it has been using its political power of persuasion in a consistent fashion.

On the EU side the fundamental principles and objectives of the withdrawal negotiations are outlined in several documents. In political terms, the most important are the Guidelines of the European Council on Brexit negotiations, which were adopted on 29 April 2017 (and updated on 15 December 2017 to take into account opening of the second phase of the withdrawal negotiations). ${ }^{51}$ As already noted, the Guidelines envisaged a phased-in approach to the exit talks and made clear that the priority of the first phase will be to give clarity and certainty to EU citizens. ${ }^{52}$ Furthermore, the Guidelines left little doubt that when it comes to EU/UK citizens, who exercise their rights before the withdrawal actually takes place, the European Union will aim to maintain a status quo. According to the European Council 'the first priority of the negotiations' are the 'reciprocal guarantees to safeguard the status and rights derived from EU law at the date of withdrawal of EU and UK citizens' ${ }^{53}$ This desiderata was clarified further in the negotiation mandate for the European Commission, which was

\footnotetext{
${ }^{45}$ For an overview of political and legal issues, which are at stake see, inter alia, House of Lords, Brexit: acquired rights, 2016, available at: https://publications.parliament.uk/pa/ld201617/ldselect/ldeucom/ 82/82.pdf.

${ }^{46}$ Shaw [38], p. 156.

${ }^{47}$ Craig [6], p. 31.

${ }^{48}$ For a comprehensive analysis of European Council and its position in the institutional system of the European Union see, inter alia, Wessels [45].

${ }^{49}$ From the institutional point of view the negotiations are conducted largely in accordance with the modus operandi envisaged for the conclusion of international agreements with third countries.

${ }^{50}$ Armstrong [1], p. 260.

${ }^{51}$ European Council (Art. 50) meeting (15 December 2017)—Guidelines, EUCO XT 20011/17.

${ }^{52}$ European Council Guidelines, p. 2.

${ }^{53}$ European Council Guidelines, para. 8.
} 
approved in May 2017. ${ }^{54}$ For instance, it envisaged that the negotiated agreement should have the same personal scope as Directive 2004/38/EC; furthermore it should cover a rich envelope of rights, which are derived from EU primary and secondary legislation. The European Parliament had proceeded along the same lines, even before the Guidelines of the European Council were approved. ${ }^{55}$ This is hardly surprising, bearing in mind that it represents EU citizens and very often picks up a banner for their rights.

The negotiating position of the United Kingdom was not as straight-forward as one could have hoped for. In February 2017 the UK Government published a White Paper, which was aimed at setting out the negotiation strategy and UK's objectives for future relations with the European Union. ${ }^{56}$ While it shed some light, it did lack detail and credible options for the future. ${ }^{57}$ Furthermore, as argued by some commentators, it was a re-jigged version of the Prime Minister's earlier Lancaster House speech. ${ }^{58}$ More details emerged only in June 2017, when the UK Government published its position on safeguarding the rights of EU/UK citizens. While its conciliatory tone was clearly visible from the opening pages, ${ }^{59}$ some of the red lines related to the acquired rights, in particular in relation to the Court of Justice and its jurisdiction, made one wonder whether a compromise was feasible at all.

With the negotiating positions in place, both sides embarked on the negotiations, which were bound to be underpinned by very high levels of complexity. In substantive terms the talks encompassed the residence rights of EU/UK citizens post-Brexit, including their family members (irrespective of their nationality). Furthermore, the talks also extended to social rights, covering co-ordination of the social security systems, access to benefits and equal treatment of EU students regarding fees at English Universities, continuation of the EU health card regime and recognition of professional qualifications. The negotiation dossiers also covered the procedural aspects of post-Brexit residence rights, their enforcement in national courts as well as the sta-

${ }^{54}$ Council Directives XT 21016/17 of 22 May 2017 for the negotiation of an agreement with the United Kingdom of Great Britain and Northern Ireland setting out the arrangements for its withdrawal from the European Union, https:/www.consilium.europa.eu/media/21766/directives-for-the-negotiation-xt21016ad01re02en17.pdf.

${ }^{55}$ European Parliament resolution P8_TA-PROV (2017)0102 of 5 April 2017 on negotiations with the United Kingdom following its notification that it intends to withdraw from the European Union, available at http://www.europarl.europa.eu/sides/getDoc.do?pubRef=-//EP//NONSGML+TA+P8-TA-2017-0102+0+ $\mathrm{DOC}+\mathrm{PDF}+\mathrm{V0//EN}$. See also: Brexit: EP outlines its red lines on latest UK citizens' rights proposal, available at: http://www.europarl.europa.eu/news/en/press-room/20171108IPR87615/brexit-ep-outlines-its-red -lines-on-latest-uk-citizens-rights-proposals.

${ }^{56}$ See further https://www.gov.uk/government/uploads/system/uploads/attachment_data/file/589191/The_ United_Kingdoms_exit_from_and_partnership_with_the_EU_Web.pdf.

${ }^{57}$ For a commentary see, inter alia, Craig [6], pp. 11-14; Polak [36], p. 1.

${ }^{58}$ As noted by Craig, it was 'in effect, the Lancaster House speech fleshed out with more facts and figures'. See Craig [6], p. 11.

${ }^{59}$ For instance, the UK Government declared that: "we will do all we can to provide reassurance to the EU citizens who have made the UK their home, and likewise for UK nationals who have done the same in countries across the EU'. See UK Government: The United Kingdom's Exit from the European Union. Safeguarding the Position of EU Citizens Living in the UK and UK Nationals Living in the EU, Cm 9464, June 2017, p. 3, available at: https://www.gov.uk/government/publications/safeguarding-the-position-of-eucitizens-in-the-uk-and-uk-nationals-in-the-eu. 
tus of case-law of the Court of Justice in the UK and its jurisdiction vis-à-vis the UK courts. The complexity of the withdrawal talks in the area in question not only resulted from the impressive list of dossiers that had to be attended to but also possible scenarios, which had to be taken into account by the negotiators. This included, exempli gratia, the status of EU/UK citizens who exercised their rights before the referendum, both those benefiting from permanent residence qua Directive 2004/38/EC but also those who - by the time of withdrawal — had not yet resided for the necessary qualifying five years. Furthermore, the negotiators had to address the rights of EU/UK citizens who opted to exercise their rights after the referendum but before Brexit. It should be noted that the status of EU citizens who arrive after Brexit was not subject to the negotiations of the Withdrawal Agreement and would be tackled, if at all, only in a treaty regulating future relations between the European Union and the United Kingdom.

\subsection{Post-referendum status of EU/UK citizens exercising their free movement rights before the withdrawal (or expiry of the transitional period)}

The negotiations of the main dossiers pencilled in for the first phase of the withdrawal negotiations took place in the summer and autumn of 2017. As expected, it was not easy to accommodate the red lines laid down by the European Union and the United Kingdom, yet eventually adequate progress was made in order to proceed to the second phase of the withdrawal talks. In early December 2017 the European Commission published its Communication on the progress in withdrawal talks and both sides published a Joint Report. ${ }^{60}$ The latter provided an overview of the agreed arrangements, while further details were left to the next phase of the exit talks. This was turned into a proper legal text and, as noted above, published by the European Commission as the Draft Withdrawal Agreement.

The parties unequivocally agreed that the objective of the agreed regime is to provide reciprocal protection of EU citizens in the United Kingdom and UK citizens in the European Union. The solutions envisaged in the future Withdrawal Agreement apply, however, only to those who exercise their rights before the 'specified date'. This term was coined by the United Kingdom in the already mentioned paper of June 2017 on the free movement of persons and was meant to cover a date somewhere between the date of notification of intention to withdraw (29 March 2017) and the date of exit. ${ }^{61}$ It should be noted that the United Kingdom eventually gave in and agreed to the EU's firm stance that the 'specified date' should mean the date of withdrawal from the European Union. However, the European Commission made it clear that, if a tailor-made transitional period were to be agreed, the 'specified date' would be the end of such a temporary regime. This was reflected in the Draft Withdrawal Agreement. ${ }^{62}$

\footnotetext{
${ }^{60}$ Communication from the Commission to the European Council (Article 50) on the state of progress of the negotiations with the United Kingdom under Article 50 of the Treaty on European Union, COM (2017) 784 final.

${ }^{61}$ See UK Government: The United Kingdom's Exit from the European Union. Safeguarding the Position of EU Citizens Living in the UK and UK Nationals Living in the EU, Cm 9464, June 2017, pp. 4-5.

${ }^{62}$ See, inter alia, Art. 9 of the Draft Withdrawal Agreement.
} 
According to Article 9 of the Draft Withdrawal Agreement, the personal scope of the post-Brexit rights of those who exercise their free movement rights in accordance with EU law before the end of the transitional period will mirror the rules currently applicable in the European Union. So, in general terms, EU/UK citizens who by then benefit from free movement rights as well as their family members defined in Article 2(2) of Directive 2004/38 and in Article 9 of the Draft Withdrawal Agreement will fall within the scope of the Withdrawal Agreement. The devil, however, is in the detail. Firstly, the EU has insisted on keeping the free movement rules operational until the expiry of the transitional period, while the United Kingdom has expressed a desire to consider the date of withdrawal as a cut-off date. Secondly, the rights of family members of migrating EU/UK citizens have remained a bone of contention. So far, the negotiators have managed to find a compromise in relation to the rights of existing family members, who either have already joined the EU/UK migrating citizens or will join them later, even after the end of the transitional period. This extends to children, who are born or adopted after that date. ${ }^{63}$ Furthermore, the United Kingdom as well as the EU Member States will have the obligation to facilitate entry and residence of the partners of EU/UK citizens who, although not resident at the specified date in the host country, will join their existing partners at a later stage. The Joint Report makes it clear that such rights will be provided in national legislation. Although the above-mentioned compromise allowed for closure of the first, and opening of the second phase of the withdrawal negotiations, it does not cover all possible scenarios. For instance, the Joint Report provides that the rights of family members not benefiting from the agreed rules will be regulated in national laws. ${ }^{64}$ This includes, exempli gratia, the rights of future spouses of EU/UK migrating citizens, who tie the knot or become partners only after the specified date. As mentioned by the European Commission in its Communication of 8 December 2017, this very matter is due to be attended to during the second phase of the negotiations as it is inherently linked to the future relations between the European Union and the United Kingdom. However, the Draft Withdrawal Agreement, which was prepared by the EU, does not exactly mirror the Joint Report and it follows the EU's negotiating position, leaving very little to future negotiations. As per Article 9(e) of the Draft Withdrawal Agreement, the family members include all family members who do not reside in the host country with EU/UK migrating citizen at the end of the transitional period. This, as explained in the footnote to the provision in question, covers also future partners/spouses of EU/UK citizens. The question is whether the proposed version of Article 9(e) of the Draft Withdrawal Agreement is acceptable to the United Kingdom. It is likely to become a stumbling block when the negotiations recommence.

One of the thorny issues, which was the subject of the negotiations throughout 2017, was the exact status of EU/UK citizens after the specified date. Since the United Kingdom expressed a desire to end free movement of persons as soon as possible it has also proposed the establishment of 'settled status' for EU migrating citizens, who exercise their free movement rights before the specified date. Although this was not

\footnotetext{
${ }^{63}$ Para. 12 of the Joint Report and Art. 9(e)(iii) of the Draft Withdrawal Agreement.

${ }^{64}$ Para. 14 of the Joint Report.
} 
welcomed with open arms by the European Union, the agreed solution clearly accommodates the wishes of the United Kingdom. According to Sect. 16 of the Joint Report, both the UK and the Member States 'can require persons concerned to apply to obtain a status conferring the rights of residence as provided for by the Withdrawal Agreement'. This is reflected in Article 17 of the Draft Withdrawal Agreement. In practice, it means that the United Kingdom may go ahead with the development of national legislation converting the rights currently enjoyed by EU citizens and their family members into settled status and require registration of the beneficiaries. The agreed solution comprises a number of requirements and benchmarks to guarantee that EU citizens and their family members are not easily deprived of their existing rights. One can argue that the strict language employed by the drafters demonstrates limited trust in the future arrangements that will be developed by the UK authorities. However, this should not come as a surprise, bearing in mind very unfortunate and well-publicised blunders by the Home Office, which in the past months has developed a tendency to send deportation letters to EU citizens and their family members who, qua EU law, have the right to reside in the United Kingdom. ${ }^{65}$ The agreed solutions make it unequivocally clear that any procedures, that are set up will be 'transparent, smooth and streamlined'. ${ }^{66}$ Furthermore, only strictly necessary information to prove the entitlement to benefit from settled status may be required. In this respect, the Draft Withdrawal Agreement follows the current regime based on Directive 2004/38/EC. Furthermore, any unnecessary administrative burdens will be prohibited, while forms to be completed by the applicants should be, as per Article 17(f) of the Draft Withdrawal Agreement be 'short, simple, user-friendly and adjusted to the context of this Agreement'. This may be easily considered as a reaction to the infamous over 80 pages long form, which EU citizens had to fill out in order to apply for the (declaratory) permanent residence card. Bearing in mind the high levels of unpreparedness on the English side of the channel, the Draft Withdrawal Agreement provides in Article 17(b) for a time limit of at least two years post the expiry of the transitional period for submission of applications. It should be noted that the period of grace, referred to as 'period of blanket permission' was already envisaged in the UK's position of June 2017 where Whitehall committed itself to giving 'adequate time to apply for [...] new residence status after [...] exit', in total for up to two years. ${ }^{67}$ The Draft Withdrawal Agreement requires any decisions to be made in accordance with objective criteria. As per Article 12(4) of the Draft Withdrawal Agreement, no discretion will be allowed to be exercised by the immigration authorities unless in favour of the applicants. Any decisions taken by relevant national authorities will be amenable to redress mechanisms and judicial control.

In order to acquire the right to reside, the pre-conditions will be the same as currently applicable under EU law, including Articles 21, 45 and 49 TFEU as well as Article 6 et al. of Directive 2004/38/EC. ${ }^{68}$ The same goes for the right of perma-

\footnotetext{
${ }^{65}$ See, for instance, Warrell [43].

${ }^{66}$ As per para. 17(e) of the Joint Report, the residence documents will be issued either 'free of charge or for a charge not exceeding that imposed on nationals for issuing of similar documents'.

${ }^{67}$ See UK Government: The United Kingdom's Exit from the European Union. Safeguarding the Position of EU Citizens Living in the UK and UK Nationals Living in the EU, Cm 9464, June 2017, p. 4 and p. 9.

${ }^{68}$ See Art. 12 of the Draft Withdrawal Agreement.
} 
nent residence, which may be acquired in accordance with Articles 16 et al. of Directive 2004/38/EC. In case of the latter, the agreed regime takes into account the already mentioned fact that many EU citizens residing in the United Kingdom have rushed to obtain their permanent residence cards. In paragraph 23 of the Joint Report, the parties agreed that these documents will be 'converted into the new document free of charge, subject only to verification of identity' as well as security checks and confirmation of on-going residence. This is confirmed in Article 17 (h) of the Draft Withdrawal Agreement. Furthermore, absences from the host state for up to five consecutive years should not deprive those EU citizens of their rights (Article 14(3) of the Draft Withdrawal Agreement).

During the negotiations a particular problem arose in relation to UK citizens residing in the European Union. While under the discussed rules their acquired rights to reside in the host country will be protected by the Withdrawal Agreement, this will not stretch to free movement rights per se. To put it differently, after Brexit (or expiry of the transitional regime) the UK citizens will not have the right to move and reside freely within the European Union. Unless a tailor-made regime is negotiated during the second phase of the negotiations, the UK citizens will become covered by EU acquis on third country nationals, including the need to obtain Schengen visas for residence.

As is well known, EU free movement rights cover not only the right to enter and to reside but also they protect individuals from unjustified restrictions. This is now regulated in Articles 27 et al. contained in Directive 2004/38/EC. Bearing this in mind the negotiators of the Withdrawal Agreement had to decide which regime would apply to EU/UK citizens, who exercise their rights before the United Kingdom leaves the EU (or before the transitional period expires). In this respect, paragraph 26 of the Joint Report clarifies that any restrictions, which are related to conduct which takes place before the expiry of the transitional period, will be governed by Chapter VI of Directive 2004/38/EC. At the same time, any conduct after the specified date will fall within the confines of national law. This is reflected in Article 18 of the Draft Withdrawal Agreement.

The rights of EU migrating citizens go well beyond residence and access to work ${ }^{69}$ and also extend to cover a number of areas. To begin with, equal treatment rights will continue to apply après Brexit, or expiry of the transitional regime. ${ }^{70}$ Furthermore, it includes, exempli gratia, co-ordination of social security legislation. In this respect the Joint Report as well as the Draft Withdrawal Agreement provide that the existing rules laid down in Regulations 883/2004 ${ }^{71}$ will apply and Article 31 of the Draft Withdrawal Agreement provides a modus operandi for securing the homogeneity of the applicable legal framework. Last but not least, Chap. 3 of the Draft Withdrawal Agreement also extends to recognition of professional qualifications ${ }^{72}$

\footnotetext{
${ }^{69}$ See Art. 22 of the Draft Withdrawal Agreement.

${ }^{70}$ See para. 31 of the Joint Report and Art. 21 of the Draft Withdrawal Agreement.

${ }^{71}$ Regulation (EC) No 883/2004 of the European Parliament and of the Council of 29 April 2004 on the coordination of social security systems [2004] OJ L 166/1.

${ }^{72}$ Directive 2005/36/EC of the European Parliament and of the Council of 7 September 2005 on the recognition of professional qualifications [2005] OJ L 255/22.
} 
including lawyers ${ }^{73}$ and approved statutory auditors, ${ }^{74}$ which will be grandfathered after withdrawal (or expiry of transitional period).

Another important aspect of free movement rights that was subject to Brexit negotiations is their enforcement at the national level. This is of particular concern when it comes to the United Kingdom, as with the day of Brexit, or at the latest, the expiry of the transitional regime, it will cut its ties with EU law and its enforcement. This will be sealed by the entry into force of the currently debated Withdrawal Bill, which, in turn, will repeal the European Communities Act 1972. ${ }^{75}$ The latter has facilitated the direct application of EU law ever since the United Kingdom joined the European Communities. One should note that the United Kingdom is a dualist country and therefore, the application of international law depends every time on formal transformation by the Parliament. Bearing this in mind, it does not come as a surprise that the EU negotiators have been particularly concerned how the Withdrawal Agreement, in particular the sections devoted to citizens' rights, will be applied après Brexit. Furthermore, as demonstrated above, the legal regime envisaged there is largely anchored in the EU acquis, which triggered a justified question as to how to secure uniform interpretation of the agreed rules. The Joint Report provides solutions in this respect and detailed rules are provided in the Draft Withdrawal Agreement. The basic arrangements are as follows. As per Article 4(4) of the Draft Withdrawal Agreement, the key concepts 'are to be interpreted in conformity with the relevant case law of the Court of Justice of the European Union handed down before the end of the transition period'. As insisted by the European Union, the Court will remain the ultimate arbiter and UK administrative authorities and courts, after the expiry of the transitional period, will have the obligation to have 'due regard' to the jurisprudence of the Luxembourg court (Article 4(5) of the Draft Withdrawal Agreement). Furthermore, the Draft Withdrawal Agreement envisages a preliminary ruling mechanism allowing the UK courts to proceed with references to the Court of Justice if litigation is triggered at the national level within eight years from the date when the regime on citizens' rights laid down in the Withdrawal Agreement becomes applicable (Article 151 of the Draft Withdrawal Agreement). In addition to this, a requirement for exchange of information between UK courts and the Court of Justice is laid down in Article 156 of the Draft Withdrawal Agreement, the UK government will have the right to intervene in cases regarding the Withdrawal Agreement pending at Kirchberg (Article 154 of the Draft Withdrawal Agreement). In the same vein, the European Commission will be guaranteed the right to intervene in cases before UK courts and tribunals (Article 155 of the Draft Withdrawal Agreement). The Joint Report as well as the Draft Withdrawal Agreement also attend to public enforcement of the agreed rules. On the EU side, this function will be performed by the European Commission

\footnotetext{
${ }^{73}$ Directive 98/5/EC of the European Parliament and of the Council of 16 February 1998 to facilitate practice of the profession of lawyer on a permanent basis in a Member State other than that in which the qualification was obtained [1998] OJ L 77/36.

${ }^{74}$ Directive 2006/43/EC of the European Parliament and of the Council of 17 May 2006 on statutory audits of annual accounts and consolidated accounts, amending Council Directives 78/660/EEC and 83/349/EEC and repealing Council Directive 84/253/EEC [2006] OJ L 157/87.

${ }^{75}$ See further Nicol [33]; Howe [19].
} 
in accordance with the infringement procedures modi operandi. The United Kingdom will have an obligation to create an independent national authority to handle, among others, individual complaints. It is notable that nuts and bolts in this respect belong to the leftovers, which are due to be attended to during the second phase of the withdrawal negotiations. However, Article 152 of the Draft Withdrawal Agreement already provides for a skeleton framework.

\subsection{Transitional regime}

As already mentioned, Article 50 TEU envisages a two-year period during which the European Union and a departing Member State are supposed to reach an agreement governing the terms of exit, taking account of future relations. Should that not happen, and the two-year period were not extended, a Member State would leave unilaterally without any formal arrangement. For anyone au courant with EU law and decision-making procedures it is rather obvious that this deadline is, if not impossible, then at least very difficult to meet. Not surprisingly the Brexit negotiations have not, during the first year, progressed at a spectacular speed. Hence, in early 2018 both sides embarked on negotiations for a transitional regime. ${ }^{76}$ This, as one could have expected, was easier said than done. When this article was completed the formal talks had not even started, yet a number of preparatory documents adopted by EU institutions in late 2017 drew a clear picture of what could be expected. At the same time, the early reactions of the UK government and, more broadly, the UK's political elite, have proved that it may be very difficult to square the circle. Against this background, the European Union prepared a set of provisions and inserted them into the Draft Withdrawal Agreement (Articles 121-126). This is likely to serve as the basis for further negotiations.

Since any transitional deal would have pivotal consequences for the free movement rights of EU/UK citizens, it was essential to put the existing proposals under scrutiny to make the present analysis as comprehensive as the dynamic political environment permitted. The starting point for any talks about transition will be the status of the United Kingdom during that crucial phase. Internal UK politics dictate that the United Kingdom will leave the European Union on 29 March 2019, that is exactly two years after notification of its intention to leave the European Union. Although it would have been way more beneficial to seek extension of the two-year period laid down in Article $50 \mathrm{TEU}$, the UK authorities signaled their firm belief that leaving the EU in 2019 was the only way forward. ${ }^{77}$ Bearing this in mind, the European Union prepared for itself a negotiation mandate based on the premise that during the period of transition the United Kingdom would already be a third country, however still a participant in the Internal Market and Customs Union. Thus, a crucial dossier that would have to be negotiated in 2018 was the extent to which it would be bound by EU acquis, in particular EU primary and secondary legislation on free movement rights. In this respect the position of the European Union was seemingly firm and unified. The United Kingdom would leave the European Union as planned,

\footnotetext{
${ }^{76}$ For a comprehensive overview see, inter alia, Lazowski [28], p. 845.

${ }^{77}$ This argument is based on the present authors' earlier publications. See Franztiou/Eazowski [13].
} 
it would not have members in the EU institutions and, consequentially, it would not participate in EU decision-making. This is made clear in Article 6 of the Draft Withdrawal Agreement. ${ }^{78}$ At the same time, it would remain bound by the EU acquis in its entirety, including any revisions or new legal acts adopted during the transition period (Article 122 of the Draft Withdrawal Agreement). This surely would extend to relevant primary and secondary legislation on movement rights. Should that happen, all principles and rules in relation to the grandfathered rights would only enter into force not at the date of Brexit (29 March 2019) but when the transitional period expires. This is reflected in the Draft Withdrawal Agreement, which treats the end of the transitional regime as the cut-off date. According to Article 121 of the Draft Withdrawal Agreement that would take place on 31 December $2020 .^{79}$ It should be remembered, however, that none of this is set in stone. Firstly, when this article was completed, it was unclear if the United Kingdom was ready to swallow such a bitter pill, putting it at a very disadvantaged position. The early reactions to the EU's negotiating position indicated that it wished to end the free movement of persons on the date of Brexit. It was unclear how such contrasting positions on both sides could be reconciled. Secondly, the conclusion and approval of the Withdrawal Agreement was also far from being a fait accompli. To put it differently, an option of unilateral withdrawal remained on the cards. Thirdly, in theoretical terms, one could also envisage a scenario whereby the two-year period would be extended and then followed by a transitional regime. If that were to happen, the free movement of persons would continue for years to come. With all those uncertainties in place one thing was clear. In early 2018 the state of affairs can only be characterised as an epicenter of chaos and uncertainty, affecting millions of EU citizens.

\subsection{Post-Brexit rights of EU and UK citizens}

The analysis presented thus far has provided an overview of the solutions agreed, which-providing that the Withdrawal Agreement enters into force-will apply to EU/UK citizens who exercise their free movement rights before the exit date or by the end of the transitional period. Such a limitation is hardly surprising as the centre of gravity during the first phase of Brexit negotiations was on already acquired rights. However, as the exit talks entered their second phase, the negotiators were expected to move on from the terms of withdrawal to future relations between the EU and the UK. Not surprisingly, immigration matters were expected to bounce back like a boomerang, together with the already mentioned few leftovers remaining unsolved after the first stage of negotiations. Although the general direction of travel was still to be decided, mainly due a short supply of credible plans and ideas at Whitehall, one thing was clear: Brexit meant Brexit and definitely the end of free movement of persons. It is notable that the UK government as early as 2017 announced the creation of a new immigration regime, even though in the period that followed it has kept on delaying publication of detailed plans. When this article was completed, the

\footnotetext{
${ }^{78}$ See also Art. 123(3) of the Draft Withdrawal Agreement.

${ }^{79}$ See also, exempli gratia, European Commission: Position Paper "Transitional Arrangements in the Withdrawal Agreement", TF50 (2018) 30, available at: https://ec.europa.eu/commission/sites/beta-political/ files/transition.pdf.
} 
publication of policy papers on the future immigration regime was pushed till the late autumn of 2018. At the same time, the business community as well as representatives of the agricultural sector were vocally expressing their concerns about post-Brexit reality and the fact that staff shortages were already starting to bite. Bearing in mind all these uncertainties one has to resort to the analysis of a few theoretical options, which potentially may be taken on board during the negotiations of future relations between the EU and the UK. They are presented in turn.

The first option is continuation of the existing regime qua a future agreement between the EU and the United Kingdom. Although, the political winds are not very promising and such an option is unlikely to materialise, one has to emphasise that, at least in theoretical terms, it may be on the cards. Experience proves that the free movement of persons may be extended to third countries, which pursues one of the models of deep integration with the European Union without actual membership. This has been referred to by the present author as, depending on circumstances, enhanced multilateralism or enhanced bilateralism. ${ }^{80}$ The example of the first is the European Economic Area, while the latter can be exemplified by the EU-Swiss Agreement on free movement of persons. Both models have one thing in common: the obligation imposed on the third countries to apply the relevant EU acquis. However, there is no one-size-fits-all approach. The European Economic Area has homogeneity and dynamism written into its DNA. To put it differently, the EEA-EFTA countries have to follow the EU acquis as it evolves and thus annexes to the EEA Agreement are regularly updated by the Joint Committees. The EU-Swiss framework is at the other end of the spectrum as it gives Switzerland considerable room for manoeuvre, which - as experience proves - it is quite happy to exercise. For instance, the Swiss government has refused to accept Directive 2004/38/EC and, therefore, the current EU-Swiss framework agreement on free movement of persons is largely based on EU secondary legislation, which was repealed in 2006. Furthermore, the future of this arrangement is now in doubt, as the Swiss government struggles to accommodate the will of its citizens expressed in a referendum held in 2016. Irrespective of those idiosyncrasies, these two models facilitate free movement of persons with countries remaining outside of the European Union. If, in an unlikely scenario, the EU and the UK opted for a comparable arrangement for their future relations, it would have to be given effect in the future general agreement between the two sides or in a tailor-made treaty. Bearing in mind the Swiss experience, the EU is very unlikely going to agree to any arrangement along the Helvetic lines. More likely, any arrangements on immigration, if at all approved by both sides, would find their home in a comprehensive free trade agreement. Yet, as already alluded to, the politics of Brexit make this option a very unlikely scenario.

The second option is a very basic regime modelled on the majority of agreements that the EU has with its neighbouring countries. For instance, the Association Agreements with the former Soviet Union countries, ${ }^{81}$ or the Stabilisation and Association

\footnotetext{
${ }^{80}$ Eazowski [24].

${ }^{81}$ Association Agreement between the European Union, the European Atomic Energy Community and their Member States, of the one part, and Ukraine, of the other part [2014] OJ L 161/3; Association Agreement between the European Union and the European Atomic Energy Community and their Member States,
} 
Agreements with the Western Balkans ${ }^{82}$ leave access to residence and work in the hands of the national authorities, yet they envisage a general non-discrimination right applicable to those who reside legally in the EU or in one of its neighbours. In matters not regulated by such agreements, the secondary legislation on immigration applies on the EU side and national rules in the third countries. When it comes to the first, it includes, exempli gratia, directives on long term residence ${ }^{83}$ or family reunification. ${ }^{84}$

The third option is a complete lack of any bilateral regime covering movement of natural persons. Should that be a desired way forward, it would leave the matters of immigration solely in the hands of the EU and its Member States, on the one side and the United Kingdom, on the other. If this scenario were to materialise, UK citizens residing at the time of Brexit, or by expiry of the transitional regime in one of the EU Member States as well as those who move after one of those dates to an EU Member State, would fall under the already mentioned EU secondary legislation on immigration and relevant national rules. EU citizens, who try their luck in the United Kingdom after Brexit, or expiry of the transitional regime, would remain solely under the confines of its, for now largely undefined, immigration rules.

This rather general fishing expedition demonstrates only a handful of options, which are available to the negotiators. Time will tell which variation is opted for, though current trends indicate a very modest resolution at the treaty level with a lot of discretion left to the EU Member States and the United Kingdom.

\subsection{Rights of EU/UK citizens in case of a unilateral Brexit}

When this article went to print the objective of the European Union and the United Kingdom was to ensure an orderly exit, based on a proper legal framework. However, although the agreement on the first phase of negotiations was reached in December 2017 and the negotiations entered their second phase, a conclusion and timely entry into force of the Withdrawal Agreement should not be treated as a fait accompli. To put it differently, one should also take into account that the United Kingdom may leave the European Union on 29 March 2019 without any formal deal. Bearing this in mind, it is essential to consider the implications of such an unregulated exit for the rights of EU/UK nationals exercising their free movement rights prior to Brexit.

of the one part, and Georgia, of the other part [2014] OJ L 261/4; Association Agreement between the European Union and the European Atomic Energy Community and their Member States, of the one part, and the Republic of Moldova, of the other part [2014] OJ L 260/4.

${ }^{82}$ Stabilisation and Association Agreement between the European Communities and their Member States, of the one part, and the Republic of Albania, of the other part [2009] OJ L 107/166; Stabilisation and Association Agreement between the European Communities and their Member States, of the one part, and the former Yugoslav Republic of Macedonia, of the other part [2004] OJ L 84/13; Stabilisation and Association Agreement between the European Communities and their Member States of the one part, and the Republic of Montenegro, of the other part [2010] OJ L 108/3; Stabilisation and Association Agreement between the European Communities and their Member States of the one part, and the Republic of Serbia, of the other part [2013] OJ L 278/14.

${ }^{83}$ Council Directive 2003/109/EC of 25 November 2003 concerning the status of third-country nationals who are long-term residents [2004] OJ L 16/44.

${ }^{84}$ Council Directive 2003/86/EC of 22 September 2003 on the right to family reunification [2003] OJ L $251 / 12$. 
To begin with, a unilateral exit would create a legal vacuum of massive proportions. As far as trade is concerned, the parties would be bound by the WTO framework, which extends to many aspects of trade, yet it falls short of addressing immigration matters. ${ }^{85}$ Consequentially, as of the date of withdrawal, EU law would cease to apply and would not be replaced by any alternative legal regime applicable between the European Union and the United Kingdom. To put it differently, the immigration status of EU citizens residing in the UK would fall primarily under national law, while UK citizens residing in the European Union would be covered by a combination of EU legislation applicable to third country nationals and domestic law. Although it is true that several provisions of human rights treaties would also apply, their enforceability would be a far cry from the standards established in the EU legal order. ${ }^{86}$ Bearing this in mind, a unilateral withdrawal not regulated properly should be considered merely as an academic proposition and should have been excluded $a b$ initio by the EU and the UK. Alas, this has not been the case and, as things stood when this article was completed, it was also considered as a viable option by members of the UK Conservative Party.

\section{Conclusions}

EU citizenship is the fundamental status of nationals of the Member States. This is a well known mantra emerging from consistent jurisprudence of the Court of Justice, starting with the landmark judgment in case C-85/96 Martinez Sala ${ }^{87}$ In many ways it seems to be set in stone. Yet not all beneficiaries of the concept in question seem to be content with what this fundamental status provides for. As is well-known, the majority of voters who cast their ballot in the UK referendum opted to give up voluntarily their EU citizenship and all the rights that come with it. Therefore, to a degree, the results of the referendum amount to failure of EU citizenship. Furthermore, EU citizenship may be perceived as a victim of its success. On the one hand, nationals of the Member States which joined the EU in the last fifteen years have eagerly exercised their free movement rights. On the other hand, it did not come to the liking of the majority covered by the franchise in the referendum. It is nobody's secret that immigration was one of the leitmotifs of the referendum campaign, even though the United Kingdom benefits from the opt-out in Schengen acquis and, hence, largely has autonomy to decide on its immigration policy vis-à-vis third countries. Not surprisingly the acquired rights of EU/UK citizens have become one of the priority areas in the Brexit negotiations. However, as experience proves, squaring the circle between political declarations and negotiations of actual law may prove to be-if not impossible - then at least a very complicated affair. Despite reassuring statements, the UK government has not provided unilateral guarantees, which would

\footnotetext{
${ }^{85}$ See House of Lords: Brexit: deal or no deal, HL 46, available at: https://publications.parliament.uk/pa/ ld201719/ldselect/ldeucom/46/46.pdf.

${ }^{86}$ See Hughes [20], p. 94.

${ }^{87}$ Case C-85/96 María Martínez Sala v Freistaat Bayern, EU:C:1998:217; Case C-413/99 Baumbast and $R v$ Secretary of State for the Home Department, EU:C:2002:493.
} 
demonstrate its good will and desire to keep the rights of EU citizens, who have already exercised their rights or will do so before Brexit, untouched. In accordance with statistical data, many EU citizens decided to migrate to other Member States (including their countries of nationality). Others opted to sit and wait for whatever the future brings or to file for naturalisation. Many UK citizens, who reside in the EU Member States proceeded along similar lines. If the Withdrawal Agreement enters into force and contains all the guarantees envisaged in the Joint Report and the Draft Withdrawal Agreement published on 28 February 2018, it should serve as a robust legal framework for protection of the acquired rights. However, much will depend on the actual enforcement of the adopted rules. The mishaps which the Home Office has experienced since the referendum send very worrying signals in this respect. Furthermore, the post-Brexit immigration regime in the United Kingdom is for now a terra incognita. The optimal way forward is either extension of the two-year period laid down in Article 50 TEU or approval and implementation of the transitional regime, during which EU law would continue to apply in the United Kingdom. This should allow sufficient time to prepare the legal framework and the state apparatus for the new reality. At the other end of the spectrum is an unregulated withdrawal, which would create a legal tsunami. Either way, EU/UK citizens who have exercised their fundamental right guaranteed by EU law are faced with an era of unprecedented uncertainty, which could have been avoided. Furthermore, it is very likely that high volumes of litigation will follow. The most recent reference for preliminary ruling submitted by a Dutch court to the Court of Justice gives a taste of what is to follow. ${ }^{88}$ Whatever the future brings, one thing seems to be certain: with the spectre of Brexit, citoyens européens became bargaining chips.

Open Access This article is distributed under the terms of the Creative Commons Attribution 4.0 International License (http://creativecommons.org/licenses/by/4.0/), which permits unrestricted use, distribution, and reproduction in any medium, provided you give appropriate credit to the original author(s) and the source, provide a link to the Creative Commons license, and indicate if changes were made.

\section{References}

1. Armstrong, K.A.: Brexit Time. Leaving the EU-Why, How and When?, Cambridge (2017)

2. Barber, T.: Six speeches to set out Brexit vision. Financial Times, 12 February 2018

3. Brady, H.: Free movement of people. In: Emerson, M. (ed.) Britain's Future in Europe. Reform, Renegotiation, Repatriation or Secession? CEPS, Brussels (2015)

4. Clarke, H.D., Goodwin, M., Whiteley, P.: Brexit. Why Britain Voted to Leave the European Union, Cambridge (2017)

5. Copsey, N., Haughton, T.: Farewell Britannia? 'Issue capture' and the politics of David Cameron's 2013 EU referendum pledge. J. Common Mark. Stud. 52, 74 (2014)

6. Craig, P.: Brexit, a drama: the Interregnum. Yearb. Eur. Law 36, 1 (2017)

7. Davies, G.: Brexit and the free movement of workers: a plea for national legal assertiveness. Eur. Law Rev. 41, 925 (2016)

8. Dougan, M. (ed.): The UK After Brexit: Legal and Policy Challenges, Cambridge (2017)

9. Ederveen, E.: The right of residency of EU citizens in the UK after Brexit. In: Hillman, J., Horlick, G. (eds.) Legal Aspects of Brexit. Implications of the United Kingdom's Decision to Withdraw from the European Union, Washington (2017)

${ }^{88}$ See McCrea [31]. 
10. Emerson, M. (ed.): Britain's Future in Europe. Reform, Renegotiation, Repatriation or Secession?, London (2016)

11. Emerson, M.: Stocktaking After Theresa May’s Brexit Speech in Florence: Key Point-The Transition, Key Omission-The Future Relationship. CEPS, 26 September 2017. https://www.ceps.eu/node/ 13036

12. Fabrini, F. (ed.): The Law \& Politics of Brexit, Oxford (2017)

13. Franztiou, E., Łazowski, A.: Brexit Transitional Period: The Solution Is Article 50. CEPS, 9 September 2017. https://www.ceps.eu/publications/brexit-transitional-period-solution-article-50

14. Goldner Lang, I.: From Association to Accession How Free Is the Free Movement of Persons in the EU, London (2011)

15. Guild, E., Peers, S., Tomkin, J.: The EU Citizenship Directive. A Commentary, Oxford (2014)

16. Hillion, C.: The European Union is dead. Long live the European Union... a commentary on the Treaty of Accession 2003. Eur. Law Rev. 29, 583 (2004)

17. Hillion, C.: Accession and withdrawal in the law of the European Union. In: Arnull, A., Chalmers, D. (eds.) The Oxford Handbook of European Union Law, Oxford (2015)

18. Hillman, J.A., Horlick, G. (eds.): Legal Aspects of Brexit: Implications of the United Kingdom's Decision to Withdraw from the European Union, Washington (2017)

19. Howe, G.: The European Communities Act 1972. Int. Aff. 49, 1 (1973)

20. Hughes, K.: Brexit and the right to remain of EU nationals. Public Law Brexit Special Issue, 94 (2017)

21. Inglis, K.: The Union's fifth accession treaty: new means to make enlargement possible. Common Mark. Law Rev. 41, 937 (2004)

22. Kluger Rasmussen, M.: 'Heavy fog in the channel. Continent cut off'? British diplomatic relations in Brussels after 2010. J. Common Mark. Stud. 54, 709 (2016)

23. Łazowski, A.: And then they were twenty-seven... a legal appraisal of the sixth accession treaty. Common Mark. Law Rev. 44, 401 (2007)

24. Łazowski, A.: Enhanced bilateralism and multilateralism: integration without membership. Common Mark. Law Rev. 45, 1433 (2008)

25. Łazowski, A.: EU do not worry, Croatia is behind you: a commentary on the seventh accession treaty. Croat. Yearb. Eur. Law Policy 8, 1 (2012)

26. Łazowski, A.: Withdrawal from the European Union and alternatives to membership. Eur. Law Rev. 37, 523 (2012)

27. Łazowski, A.: Brexit referendum: beginning of the end or just a turning point? Eur. Pap. 1, 377 (2016)

28. Łazowski, A.: Exercises in legal acrobatics: the Brexit transitional arrangements. Eur. Pap. 2, 845 (2017)

29. Łazowski, A.: Inside but out: United Kingdom and the EU. In: Jakab, A., Kochenov, D. (eds.) The Enforcement of EU Law. Methods Against Member States' Defiance, Oxford (2017)

30. Manning, P.: Migration in World History, 2nd edn. Routledge, London (2012)

31. McCrea, R.: Brexit EU Citizenship Rights of UK Nationals and the Court of Justice. U.K. Const. L. Blog, 8 February 2018. https://ukconstitutionallaw.org/

32. Mikes, G.: How to Be a Brit. Penguin, Baltimore (2015)

33. Nicol, D.: EC Membership and Judicialization of British Politics, Oxford, (2001)

34. Peers, S.: EU Justice and Home Affairs, 4th edn. Oxford University Press, London (2016)

35. Peers, S., Harvey, D.: Brexit: the legal dimension. In: Barnard, C., Peers, S. (eds.) European Union Law, Oxford (2017)

36. Polak, R.P.: Brexit: Theresa May's red lines get tangled up in her red tape. A commentary on the white paper. Eur. Pap. 2, 1 (2017)

37. Rieder, C.M.: The withdrawal clause of the Lisbon Treaty in the light of EU citizenship: between disintegration and integration. Fordham Int. Law J. 37, 147 (2013)

38. Shaw, J.: Citizenship and free movement in a changing EU. Navigating an archipelago of contradictions. In: Martill, B., Staiger, U. (eds.) Brexit and Beyond. Rethinking the Futures of Europe, London (2018)

39. Tatham, A.: Enlargement of the European Union, The Hague (2009)

40. Tatham, A.F.: Don't mention divorce at the wedding, darling!: EU accession and withdrawal after Lisbon. In: Biondi, A., Eeckhout, P., Ripley, S. (eds.) EU Law After Lisbon, Oxford (2012)

41. van der Harst, J., Hoogers, G., Voerman, G. (eds.) European Citizenship in Perspective. History, Politics and Law, Cheltenham (2018)

42. Warrel, H.: UK admits permanent residency application process cannot cope. Financial Times, 27 April 2017 
43. Warrell, H.: About 100 EU nationals told to leave Britain-by mistake. Financial Times, 23 August 2017

44. Weiss, S., Blockmans, S.: The EU Deal to Avoid Brexit: Take It or Leave. CEPS (2016)

45. Wessels, W.: The European Council, London (2016)

46. Wintour, P.: 'Go home' billboard vans not a success, says Theresa May. The Guardian, 22 October 2013. https://www.theguardian.com/politics/2013/oct/22/go-home-billboards-pulled 